\title{
Optimization of M-PERT \& BIM 5D to Minimize the Risk of Time Delay \& Overrun in Stadium Project Structure Works: Key Success Factors
}

\author{
Ahmad Sholichan ${ }^{1}$, Albert Eddy Husin ${ }^{2}$ \\ ${ }^{1}$ Postgraduate Students of Master Civil Engineering, Universitas Mercu Buana, Jakarta, Indonesia \\ ${ }^{2}$ Lecturer of Master Civil Engineering, Universitas Mercu Buana, Jakarta, Indonesia
}

Corresponding Author: Ahmad Sholichan

\begin{abstract}
Time delays and cost overrun are still a "scourge" in construction projects. The most important factors that cause these two risks are ineffective project planning and scheduling, and inaccurate quantity taking off. Thus, it is most appropriate to carry out mitigation since the project planning period. With the fact of increasing stadium construction in various countries, with iconic and futuristic design, and containing national pride, must be a serious concern so that the risk of time delay \& cost overrun can be reduced. Because stadiums are like that usually involve a complex structural system, complicated installation technique with strict network diagrams. The M-PERT \& BIM 5D - Based Quantity Take Off method has the potential to mitigate and minimize this risk. This study, with the RII simulation, reveals the critical success factor for applying the potential of this method, especially in stadium structural work. These factors can become a serious concern for construction practitioners, especially in Indonesia, who are and will build stadium projects.
\end{abstract}

Keywords: Structure; Stadium; M-PERT; BIM $5 \mathrm{D} ; \mathrm{RII}$

\section{INTRODUCTION}

The increasing number of sport events in the world has encouraged various countries to compete to build and develop sports facilities, especially stadiums. The high demands on stadium standards from the relevant federations, coupled with the stakes of national pride, have pushed the country appointed to host the sporting event to make various renovations to the existing stadium, even to the extent of spending large budgets for the construction of a new stadium, more iconic and more futuristic. This also happened in Indonesia, after successfully organizing the 2018 Asian Games and being appointed as the host of the 2021 FIFA U-20 World Cup, construction of stadium broke out in various regions of Indonesia.

What should be noted in the construction and renovation of the stadium is that the characteristics of the stadium building have a very high risk of causing project failure, both in the form of time delays and cost overruns. For example, the construction of the 2008 Beijing Olympic Games Bird's Nest Stadium recorded a 6month delay from schedule - approximately $12 \%$-, which forced the retractable roof from the original design to be removed. The project also experienced cost increases from 1.6 - 2 billion RMB to 3.5 billion RMB (Liang et al., 2011). Ineffective project planning and scheduling was noted as the most important factor causing project delays, apart from inadequate contractor experience (Gündüz et al., 2013). While the main causes of cost overruns are inaccurate material estimates, project complexity \& inaccurate quantity take-off (Bekker,2011). Bekr (2015) also noted that "inaccurate quantity taking off" \& errors in the bill of 
quantities were a significant factor causing uncontrollable costs.

Stadiums with iconic designs, futuristic and containing national pride, usually involve a complex structural system, complicated installation technique with strict network diagrams. Moreover, if the stadium being built is an Olympic Stadium type, then the structural work will be the most decisive constrain. This is because athletic track work cannot be done if the work area is not free from heavy equipment activities or construction support tools used to carry out structural work and steel roof truss work.

KPMG Sports Advisory (2013) in "A Blueprint for Successful Stadium Development" states that the construction of the stadium structure is the core that gives the general shape of the stadium. So that apart from being a major job, structural work is also a critical job. UEFA (2011) in the "UEFA Guide to Quality Stadiums" states that structural work is the largest cost component in the construction of the stadium, reaching $37.86 \%$. Thus the cost control of this work becomes a critical and decisive point to avoid over-budgeting.

In order to respond to the phenomenon of the problems above and to answer them, the following method approaches were initiated:

a. M-PERT method or Manual Program Evaluation Review and Technique, which is a renewable innovation from the PERT method, is proven to provide an accuracy of planning implementation time of 99\% (Ballesteros-Pérez, 2017)

b. BIM 5D - Based Quantity Take Off to answer cost performance problems. McGraw-Hill Construction Research and Analytic in Hardin \& McCool (2015) released that BIM has the potential to reduce construction costs by up to $43 \%$.

Both methods have the potential to minimize the risk of time delays and project cost overruns. Thus it is interesting to prove. The question, apart from how to optimize the potential of the method in construction projects, is what are the critical success factors for optimizing the M-PERT \& BIM $5 \mathrm{D}$ method. For this reason, before being tested with case studies on selected projects, this research was carried out, namely a study of the factors that most influence the optimization of M-PERT \& BIM 5D to minimize the risk of time delays and cost overruns in buildings, especially structural work on stadium projects. With the identification of the key success factors, it can be input for construction industry, especially in Indonesia, in optimizing the potential of M-PERT \& BIM 5D, to improve project performance and efficiency.

\section{Identification and Categorization of Key Success Factors for Optimizing M-PERT \& BIM 5D}

From the results of the literature study and justification from construction experts, 42 sub-factors were identified and defined which were categorized into 11 main factors in 3 variables, as follows:

- Duration analysis, identified as one of the main factors of the M-PERT variable, which consists of 5 sub factors: combination \& merger of project activities, simplification of the activity network, and ease of application (duration estimation can be done manually), high accuracy between planned and actual construction projects and the resulting output is accurate, but not complicated to use as a control tool (Ballesteros-Pérez, 2017) (Husin \& Ashadi, 2019)

- Activity \& Network Definition, the main factor for PERT variable, consists of 4 sub-factors: Defining Activities in Work Breakdown Structure, activity network estimation (logic relationship) and making network diagrams (Prasetiowati, 2015), and distribution of activity duration (Hajdu, 2013).

- Develop Scheduling, for the PERT variable, consisting of 4 sub-factors: the final target of project scheduling and scheduling in specific activities so that the project can be completed on time 
(Lu \& S. M. AbouRizk, 2000), and work that must be started earlier and work that must be completed early (Hajdu, 2013).

- QS BIM (Quantity Surveying) which is the main factor of the 5D BIM variable group, consisting of 4 sub factors: education and age QS BIM (Qiping Shen \& Guiwen Liu, 2014), operator experience \& productivity (The Tavistock Institute, 2016), number of QS team members (Leung \& Kong, 2017) and operator/QS remuneration (Hansae Kim, 2004).

- The BIM 5D QTO (Quantity Take Off) process from the QS BIM variable, broken down into 5 sub factors: 3D modelling details (Chegu Badrinath \& Hsieh, 2019), Data Interoperability, Subcontractor \& Supplier pricing (Choi et al., 2015), Quantity Take Off (Elbeltagi et al., 2014), and Cost database (Smith, 2014).

- The 6 main factors are further grouped into Stadium Structure variables, namely Project Complexity, DED Document, Cost and Time, Elements of Structure, Resource Management and External \& Internal Factors. Project complexity has 5 sub-factors including stadium type and capacity (Lavy et al., 2005), Contract Type: Design \& Build or Construction (Liang et al., 2011); (Hongchang \& Hongyu, 2012); (Yuan et al., 2010), Unrealistic scope, schedule and budget (Christ Hendrickson, 2013), The presence of a retractable roof (Liang et al., 2011); (Luca et al., 2018); (Mans \& Rodenburg, 2001), and Iconic Design (Lavy et al., 2005); (Yuan et al., 2010).

- DED (Detail Engineering Design) document, which includes 3 sub-factors, namely detailed drawings and clear specifications (Kaming et al., 2010) ; (Akhund et al., 2017), Completeness of Bill of Quantity (Woo \& Bui, 2007), and Work Schedule (Ugw Kumarswarmy, 2015)

- Cost and Time, including 4 sub-factors, namely Design Changes (Kaming et al., 2010); (Akhund et al., 2017),
Complicated installation techniques and strict Network Diagrams (Cole \& Hulme, 2011), and Planned time for construction work (Bhangale, 2016)

- Structural Elements, consisting of 4 subfactors: Structural Design Complexity (Lavy et al., 2005); (Bosela \& Delatte, 2011), Diversity of types and sizes of structural elements (foundations, beams, columns) (Nie et al., 2018), Types of Formwork / Temporary Work used (Mehdizadeh et al., 2013) ; (Boyle et al., 2009), and Suitability of structural design to standards \& codes (Mehdizadeh et al., 2013).

- Resource Management, consisting of 4 sub-factors: Delays due to shortages and material delays (Bhangale, 2016), Control of resources (Kaotsikouri et al.,2008), Selection of competent subcontractors and Productivity of Project Resources (manpower, equipment) (Kaming et al., 2010) ; (Akhund et al., 2017).

- External \& Internal Factors, which include 4 sub-factors namely Accessibility to location (Amran et al, 2019), Technology Use (Chan et al, 2004); (Zhiliang et al., 2004), Teamwork (Abdullah et al., 2015), Management Communication and Support; (Mallawaarachchi et al, 2015) and Culture of Collaboration between team members (Chen \& Chen, 2007).

\section{METHODS}

This research was formulated using a qualitative method with a simulation tool, namely the RII (Relative Importance Index) analysis based on the research instrument, namely a questionnaire, which we distributed to selected respondents. An interview questionnaire was developed to assess the perceptions of practitioners of the Indonesian construction industry, with qualifications of Project Manager, Project Engineering Manager, Site Manager, Scheduler, QS, Cost Control, Supervisor, and preferably those who have worked on stadium projects, about the important factors 
that determine the success of optimizing the M-PERT \& BIM 5D methods.

The results of the questionnaire were processed and analyzed by the RII method until the ranking of the factors that most influence the success of optimizing the MPERT \& BIM 5D method to minimize the risk of time delays and cost overruns in stadium structure work. The RII value has a range from 0 to 1 (the value 0 is not included). The highest RII score will be the most influential factor in the study. RII is then ranked for each sub factor. The calculation of the average RII value is used as the RII value for each main factor contained in the sub factor. The result is a ranking of sub-factors, main factors and variables (Gündüz et al., 2013).

\section{RESULT AND DISCUSSION}

The value data in the tabulation of the questionnaire results is processed by the RII analysis, using equation (1)
RII (sub factor) $=\frac{\sum W}{(A \times N)}$

$\mathrm{RII}=$ Relative Importance Index

$\mathrm{W}=$ weighting given to each factor by the respondents (ranging from 1 to 6 )

$A=$ The highest weight (in this study 6 )

$\mathrm{N}=$ Total respondents

RII Main factor $=$ mean RII sub-factor value RII Variable $=$ mean RII main factor value

The influence relationship between the main factors and the purpose of this research analysis is illustrated in Figure 1, in the form of a fishbone diagram or known as the Ishikawa Diagram. On the fish head is the purpose of the analysis of this study, namely minimizing the risk of time delays and over budget, which in the end is able to improve time and cost performance, with a framework component that contains the main factor as a determinant in achieving these goals.

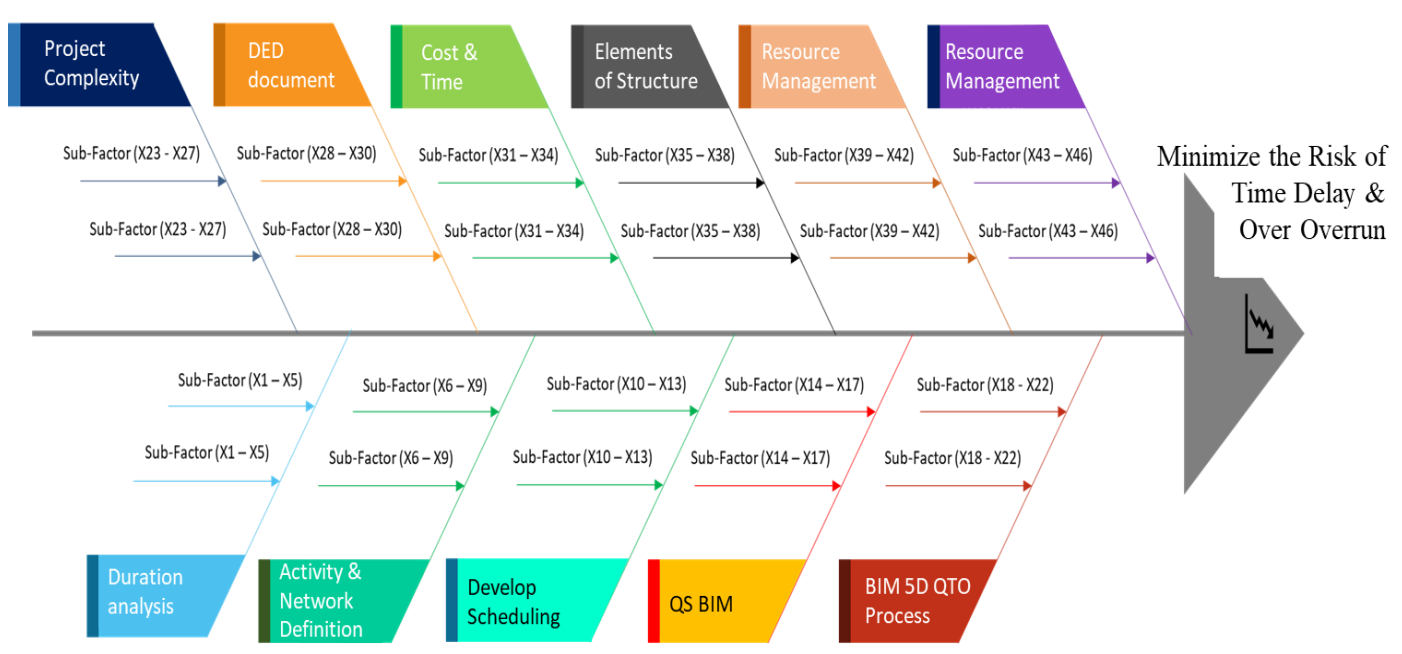

Figure 1. Main Factor \& Sub Factor Category of Successful Optimization of M-PERT \& BIM 5D

\section{Results of the Study of Key Success Factors with RII}

From the simulation of factor ratings with RII shown in Table 1, it was found that 10 most determine the success of the optimization of M-PERT \& BIM 5D to help the development of time and budget delays in buildings, especially structural work on stadium projects (Table 2), as well as factors - factors whose influence is at the lowest level (Table 3). The configuration of the influence on each of the main factors is described as follows.

a. Duration Analysis (RII = 0,952)

Has the highest RII value, thus Duration Analysis is the most influential main factor that determines the success of optimizing M-PERT \& BIM 5D in this study. In this main factor, the most influential sub-factors sequentially are 
Ahmad Sholichan et.al. Optimization of M-PERT \& BIM 5D to minimize the risk of time delay \& overrun in stadium project structure works: key success factors.

the simplification of the activity network $(\mathrm{RII}=0.984)$; combination \& merger of project activities $(\mathrm{RII}=0.980)$; and high accuracy between planned and actual construction projects $(\mathrm{RII}=0.976)$.

b. Activity \& Network Definition (RII = 0,927)

With the RII value, this main factor ranks as the third most influential main factor in this study. Sequentially, the most influential sub-factors in this group are the Defining Activities in Work
Breakdown Structure $(\mathrm{RII}=0.940)$; activity network estimation (logic relationship) $(\mathrm{RII}=0.940)$; and Making of Network Diagrams (RII $=0.937)$.

c. Develop Scheduling $(\mathrm{RII}=\mathbf{0 , 9 2 9})$

In this main factor, the most influential sub factor is the final target of project scheduling (RII = 0.897); and Scheduling in special activities so that the project can be completed on time $(\mathrm{RII}=0.861)$.

\begin{tabular}{|c|c|c|c|c|c|c|c|c|c|c|}
\hline \multirow{2}{*}{$\begin{array}{l}\text { Main } \\
\text { Factor }\end{array}$} & \multirow[t]{2}{*}{ Code } & \multirow[t]{2}{*}{ Sub Factors } & \multicolumn{6}{|c|}{ Score Recapitulation } & \multirow[t]{2}{*}{ RII } & \multirow[t]{2}{*}{ Rangking } \\
\hline & & & 1 & 2 & 3 & 4 & 5 & 6 & & \\
\hline \multirow{4}{*}{$\begin{array}{l}\text { Duration } \\
\text { analysis }\end{array}$} & $\mathrm{X} 1$ & Combination \& merger of project activities & - & - & - & - & 5 & 37 & 0,980 & 3 \\
\hline & $\mathrm{X} 3$ & Ease of application (duration estimation can be done manually) & - & - & - & - & 24 & 18 & 0,905 & 22 \\
\hline & $\mathrm{X} 4$ & High accuracy between planned and actual construction projects & - & - & - & - & 6 & 36 & 0,976 & 4 \\
\hline & $\mathrm{X} 5$ & $\begin{array}{l}\text { Resulting output is accurate, but not complicated to use as a control } \\
\text { tool }\end{array}$ & - & - & - & - & 21 & 21 & 0,917 & 19 \\
\hline \multirow{4}{*}{$\begin{array}{l}\text { Activity \& } \\
\text { Network } \\
\text { Definition }\end{array}$} & $\mathrm{X} 6$ & Defining Activities in Work Breakdown Structure & - & - & - & - & 15 & 27 & 0,940 & 13 \\
\hline & $\mathrm{X} 7$ & Activity network estimation (logic relationship) & - & - & - & - & 16 & 26 & 0,937 & 14 \\
\hline & $\mathrm{X} 8$ & Distribution of activity duration & - & - & - & - & 25 & 17 & 0,901 & 23 \\
\hline & $\mathrm{X} 9$ & Making network diagrams & - & - & - & - & 18 & 24 & 0,929 & 16 \\
\hline \multirow{3}{*}{$\begin{array}{l}\text { Develop } \\
\text { Scheduling }\end{array}$} & $\mathrm{X} 10$ & Final target of project scheduling & - & - & - & - & 26 & 16 & 0,897 & 24 \\
\hline & $\mathrm{X} 11$ & $\begin{array}{l}\text { Scheduling in specific activities so that the project can be completed } \\
\text { on time }\end{array}$ & - & - & - & - & 35 & 7 & 0,861 & 32 \\
\hline & $\mathrm{X} 12$ & Work that must be started earlier & - & - & - & 5 & 37 & - & 0,813 & 39 \\
\hline \multirow[t]{4}{*}{ QS BIM } & $\mathrm{X} 14$ & Education and age QS BIM & - & - & 3 & 12 & 27 & - & 0,762 & 44 \\
\hline & $\mathrm{X} 15$ & Operator experience \& productivity & - & - & - & - & 30 & 12 & 0,881 & 28 \\
\hline & $\mathrm{X} 16$ & Number of QS team members & - & - & - & 13 & 29 & - & 0,782 & 43 \\
\hline & $\mathrm{X} 17$ & Operator/QS remuneration & - & - & - & - & 37 & 5 & 0,853 & 33 \\
\hline \multirow{5}{*}{$\begin{array}{l}\text { BIM 5D - } \\
\text { QTO } \\
\text { Process }\end{array}$} & $\mathrm{X} 18$ & 3D modeling details & - & - & - & - & 8 & 34 & 0,968 & 6 \\
\hline & $\mathrm{X} 19$ & Data Interoperability & - & - & - & - & 31 & 11 & 0,877 & 29 \\
\hline & $\mathrm{X} 20$ & Quantity Take Off & - & - & - & - & 9 & 33 & 0,964 & 7 \\
\hline & $\mathrm{X} 21$ & Cost database & - & - & - & - & 29 & 13 & 0,885 & 27 \\
\hline & $\mathrm{X} 22$ & Subcontractor \& Supplier pricing & - & - & - & 2 & 36 & 4 & 0,841 & 34 \\
\hline \multirow{5}{*}{$\begin{array}{l}\text { Project } \\
\text { complexity }\end{array}$} & $\mathrm{X} 23$ & Stadium type and capacity & - & - & - & - & 13 & 29 & 0,948 & 11 \\
\hline & $\mathrm{X} 24$ & Contract Type: Design \& Build or Construction & - & - & - & - & 14 & 28 & 0,944 & 12 \\
\hline & $\mathrm{X} 25$ & Unrealistic scope, schedule and budget & - & - & - & - & 2 & 40 & 0,992 & 1 \\
\hline & $\mathrm{X} 26$ & The presence of a retractable roof & - & - & - & 1 & 20 & 21 & 0,913 & 20 \\
\hline & $\mathrm{X} 27$ & Iconic Design & - & - & - & - & 19 & 23 & 0,925 & 17 \\
\hline \multirow{2}{*}{$\begin{array}{l}\text { DED } \\
\text { document }\end{array}$} & $\mathrm{X} 28$ & Detailed drawings and clear specifications & - & - & - & - & 10 & 32 & 0,960 & 8 \\
\hline & $\mathrm{X} 29$ & Completeness of Bill of Quantity & - & - & - & - & 11 & 31 & 0,956 & 9 \\
\hline \multirow{3}{*}{$\begin{array}{l}\text { Cost and } \\
\text { Time }\end{array}$} & $\mathrm{X} 32$ & Complicated installation techniques & - & - & - & - & 12 & 30 & 0,952 & 10 \\
\hline & $\mathrm{X} 33$ & Strict Network Diagrams & - & - & - & - & 17 & 25 & 0,933 & 15 \\
\hline & X34 & Planned time for construction work & - & - & - & 4 & 38 & & 0,817 & 38 \\
\hline \multirow{4}{*}{$\begin{array}{l}\text { Structural } \\
\text { Elements }\end{array}$} & $\mathrm{X} 35$ & Structural Design Complexity & - & - & - & - & 7 & 35 & 0,972 & 5 \\
\hline & $\mathrm{X} 36$ & $\begin{array}{l}\text { Diversity of types and sizes of structural elements (foundations, } \\
\text { beams, columns) }\end{array}$ & - & - & - & - & 20 & 22 & 0,921 & 18 \\
\hline & $\mathrm{X} 37$ & Types of Formwork / Temporary Work used & - & - & - & 8 & 34 & - & 0,802 & 41 \\
\hline & $\mathrm{X} 38$ & Suitability of structural design to standards \& codes & - & - & 2 & 8 & 32 & - & 0,786 & 42 \\
\hline \multirow{4}{*}{$\begin{array}{l}\text { Resource } \\
\text { Management }\end{array}$} & X39 & Delays due to shortages and material delays & - & - & - & 3 & 37 & 2 & 0,829 & 37 \\
\hline & $\mathrm{X} 40$ & Control of resources & - & - & - & - & 28 & 14 & 0,889 & 26 \\
\hline & $\mathrm{X} 41$ & Selection of competent subcontractors & - & - & - & - & 34 & 8 & 0,865 & 31 \\
\hline & $\mathrm{X} 42$ & Productivity of Project Resources (manpower, equipment) & - & - & - & - & 27 & 15 & 0,893 & 25 \\
\hline \multirow{4}{*}{$\begin{array}{l}\text { External \& } \\
\text { Internal } \\
\text { Factors }\end{array}$} & $\mathrm{X} 43$ & Accessibility to location & - & - & 2 & 17 & 23 & - & 0,750 & 46 \\
\hline & $\mathrm{X} 44$ & Technology Use & - & - & - & 20 & 22 & - & 0,754 & 45 \\
\hline & $\mathrm{X} 45$ & Teamwork, Management Communication and Support & - & - & - & 2 & 37 & 3 & 0,837 & 35 \\
\hline & $\mathrm{X} 46$ & Culture of Collaboration between team members & - & - & - & - & 32 & 10 & 0,873 & 30 \\
\hline
\end{tabular}

Information on Respondents' Score on the Level of Influence of Sub-Factors / Likert Scale: (1) Strongly Disagree; (2) Disagree; (3) Disagree; (4) Somewhat Agree; (5) Agree; (6) Strongly Agree 


\section{d. $\mathbf{Q S ~ B I M ~}(\mathrm{RII}=\mathbf{0 , 8 1 9})$}

With the RII value, this main factor has the second lowest rank. The sub-factor that most influences the success of this main factor is Operator Experience \& Productivity (RII value $=0.880)$. The BIM QS Education and Age sub-factors assessed by respondents are not factors that determine the success of 5D BIM optimization, because they are only ranked 44th in the overall sub-factor (with an RII value $=0.762$ )

e. BIM 5D - QTO Process (RII = 0,907)

With the most influential sub factor, namely 3D modelling details (RII = 0.968); and Quantity Take Off (RII = 0.964), then this main factor is ranked fifth for the main factor that has the most influence on success.

\section{f. $\quad$ Project Complexity (RII = 0,944)}

Ranked second as the most influential main factor, with the sub factor with the largest value, namely RII $=0.992$ for Unrealistic scope, schedule and budget; RII $=0.948$ for Stadium Type and Capacity; and RII $=0.944$ for the subfactor Type of Contract: Design \& Build or Construction. The iconic design and the presence of a retractable roof were also assessed by respondents as quite influential factors, with RII values of 0.924 and 0.912 , respectively.

g. DED Document (RII = 0,917)

With the RII value, this main factor has the fourth rank in this study. This means that the sub-factors of Detailed Drawings and Clear of Specifications, Completeness of Bill of Quantity and Work Schedules must also be a concern in optimizing the potential of M-PERT \& BIM 5D.

h. Cost and Time (RII $=\mathbf{0 , 9 0 3 )}$

In this main factor, the most influential sub-factor is a complicated installation technique, with an RII value of 0.952 .

i. Structural Elements ( $R I I=\mathbf{0 , 8 7 0})$

In ranking, it is under the main factor Cost and Time, although the sub-factor of Complexity of Structural Design is ranked 5th out of all sub-factors. j. $\quad$ Resource Management $(\mathbf{R I I}=\mathbf{0 , 8 6 9})$

Ranked in the 8th most influential main factor.

k. External \& Internal Factors (RII = 0,804)

This main factor is rated by respondents as the least influential in the success of optimizing the potential of M-PERT \& BIM 5D.

Furthermore, the results of the RII analysis as shown in Table 1 are summarized and arranged in the form of a ranking, which consists of 10 (ten) most influential sub-factors and insignificant influencing factors. The results are shown in Table 2 and Table 3.

Table 2. 10 Most Influential Factors, with RII value

\begin{tabular}{|c|c|c|c|}
\hline Code & Sub Factors & RII & Ranking \\
\hline $\mathrm{X} 25$ & $\begin{array}{l}\text { Unrealistic scope, schedule and } \\
\text { budget }\end{array}$ & 0,992 & 1 \\
\hline $\mathrm{X} 2$ & $\begin{array}{l}\text { Simplification of the activity } \\
\text { network }\end{array}$ & 0,984 & 2 \\
\hline $\mathrm{X} 1$ & $\begin{array}{l}\text { Combination \& merger of } \\
\text { project activities }\end{array}$ & 0,980 & 3 \\
\hline $\mathrm{X} 4$ & $\begin{array}{l}\text { High accuracy between } \\
\text { planned and actual construction } \\
\text { projects }\end{array}$ & 0,976 & 4 \\
\hline $\mathrm{X} 35$ & Structural Design Complexity & 0,972 & 5 \\
\hline $\mathrm{X} 18$ & 3D modeling details & 0,968 & 6 \\
\hline $\mathrm{X} 20$ & Quantity Take Off & 0,964 & 7 \\
\hline $\mathrm{X} 28$ & $\begin{array}{l}\text { Detailed drawings and clear } \\
\text { specifications }\end{array}$ & 0,960 & 8 \\
\hline $\mathrm{X} 29$ & $\begin{array}{l}\text { Completeness of Bill of } \\
\text { Quantity }\end{array}$ & 0,956 & 9 \\
\hline X32 & $\begin{array}{l}\text { Complicated } \\
\text { techniques }\end{array}$ & 0,952 & 10 \\
\hline
\end{tabular}

Table 3. 10 Insignificant Influencing Factors, with RII value

\begin{tabular}{|l|l|l|l|}
\hline Code & Sub Factors & RII & Ranking \\
\hline X39 & $\begin{array}{l}\text { Delays due to shortages and } \\
\text { material delays }\end{array}$ & 0,829 & 37 \\
\hline X34 & $\begin{array}{l}\text { Planned time for construction } \\
\text { work }\end{array}$ & 0,817 & 38 \\
\hline X12 & Work that must be started earlier & 0,813 & 39 \\
\hline X13 & $\begin{array}{l}\text { Work that must be completed } \\
\text { early }\end{array}$ & 0,810 & 40 \\
\hline X37 & $\begin{array}{l}\text { Types of Formwork / Temporary } \\
\text { Work used }\end{array}$ & 0,802 & 41 \\
\hline X38 & $\begin{array}{l}\text { Suitability of structural design to } \\
\text { standards \& codes }\end{array}$ & 0,786 & 42 \\
\hline X16 & Number of QS team members & 0,782 & 43 \\
\hline X14 & Education and age QS BIM & 0,762 & 44 \\
\hline X44 & Technology Use & 0,754 & 45 \\
\hline X43 & Accessibility to location & 0,750 & 46 \\
\hline
\end{tabular}

\section{CONCLUSION}

The risk of time delays \& cost overruns on stadium project structure work can be mitigated early on by minimizing the main causes of these risks, namely poor project planning and scheduling and 
inaccurate take-off quantities, by optimizing the potential of the M-PERT and BIM 5D methods. Based on the results of the study, it was found that the factors that most influence the success of optimizing $\mathrm{M}$ PERT \& BIM 5D to minimize the risk of time delays and over budget in buildings, especially structural work on stadium projects, sequentially are a) Unrealistic scope, schedule and budget ; b) Simplification of the network of activities (network); c) Combination \& Merger of project activities; d) High accuracy between planned and actual construction projects; e) Complexity of Structural Design; f) Details of 3D modelling; g) Quantity Take Off; h) Detailed Drawings and Clear of Specifications; i) Completeness of Bill of Quantity; j) Complicated installation technique.

\section{ACKNOWLEDGMENTS}

This research is fully supported by Adhi Karya, one of the major Indonesian state-controlled construction companies, including Mr. Wardana Wikrama, Mr. Soni Ariawan, Mr. Muntohar, and BIMA - BIM Team Adhi. I am very honored to be involved and collaborate with The Surakarta Manahan Stadium Project Team to participate in accelerating the implementation of BIM in Indonesia, towards Construction 4.0.

\section{Conflict of Interest: None}

\section{Source of Funding: None}

\section{REFERENCES}

1. Ballesteros-Pérez, P. (2017). M-PERT: Manual Project-Duration Estimation Technique for Teaching Scheduling Basics. Journal of Construction Engineering and Management.

https://doi.org/10.1061/(ASCE)CO.19437862.0001358

2. Bekker, M. C. (2011). Causes of construction cost and time overruns: The 2010 FIFA World Cup stadia in South Africa. Acta Structilia, June 2011.
3. Bekr, G. A. (2015). Identifying Factors Leading to Cost Overrun in Construction Projects in Jordan. Journal of Construction Engineering, Technology and Management, 5(3), 25-33.

4. Chegu Badrinath, A., \& Hsieh, S. H. (2019). Empirical Approach to Identify Operational Critical Success Factors for BIM Projects. Journal of Construction Engineering and Management, $145(3)$. https://doi.org/10.1061/(ASCE)CO.19437862.0001607

5. Choi, J., Kim, H., \& Kim, I. (2015). Open BIM-based quantity take-off system for schematic estimation of building frame in early design stage. Journal of Computational Design and Engineering, 2(1), 16-25. https://doi.org/10.1016/j.jcde.2014.11.002

6. Elbeltagi, E., Hosny, O., Dawood, M., \& Elhakeem, A. (2014). BIM-Based Cost Construction Estimation / Monitoring For Building. Emad Elbeltagi Int. Journal of Engineering Research and Applications, $4(7), 56-66$.

7. Gündüz, M., Nielsen, Y., \& Özdemir, M. (2013). Quantification of delay factors using the relative importance index method for construction projects in Turkey. Journal of Management in Engineering, 29(2), 133139.

https://doi.org/10.1061/(ASCE)ME.19435479.0000129

8. Hajdu, M. (2013). Effects of the application of activity calendars on the distribution of project duration in PERT networks. Automation in Construction, 35, 397-404. https://doi.org/10.1016/j.autcon.2013.05.025

9. Hardin, B., \& McCool, D. (2015). BIM and Construction Management: Proven Tools, Methods, and Workflows. In John Wiley \& Sons.

10. Hongchang, L., \& Hongyu, L. (2012). Research on the Risk of College Stadiums BOT Project and Countermeasures. 113, 395-401. https://doi.org/10.1007/978-94007-2169-2

11. Husin, A. E., \& Ashadi, R. F. (2019). Metode Penjadwalan M-PERT Sebagai Alternatif Solusi Akurasi Estimasi Waktu Proyek ( Review ). Jurnal Aplikasi Teknik Sipil, $\quad$ February. https://doi.org/10.13140/RG.2.2.33009.9456 7

12. KPMG Sports Advisory. (2013). A Blueprint for Successful Stadium 
Ahmad Sholichan et.al. Optimization of M-PERT \& BIM 5D to minimize the risk of time delay \& overrun in stadium project structure works: key success factors.

Development.

35. https://www.footballbenchmark.com/docum ents/files/public/blueprint-successfulstadium-development.pdf

13. Lavy, S., Shapira, A., Botansky, Y., \& Schexnayder, C. J. (2005). Challenges of stadium construction-case study. Practice Periodical on Structural Design and Construction, 10(3), 181-189. https://doi.org/10.1061/(ASCE)10840680(2005)10:3(181)

14. Liang, W., Song, X., \& Wang, S. (2011). Case study of the Bird's Nest: Risks and opportunities in China's PPP implementations in major sports facilities. Advanced Materials Research, 243249(December 2003), 6332-6338. https://doi.org/10.4028/www.scientific.net/ AMR.243-249.6332

15. Lu, M., \& S. M. AbouRizk. (2000). Simplified CPM/PERT Simulation Model. Journal of Construction Engineering and Management, 9364(January / February), 5260. https://doi.org/10.1061/(ASCE)07339364(2000) 126

16. Luca, A. De, Cao, L., Pinto, M., Malsch, E., \& Duffy, T. (2018). Rails in Retractable Roofs: Overview of the Design
Methodology and a Case Study. Forensic Engineering 2018, 1984, 417-425.

17. Mans, I. D. G., \& Rodenburg, J. (2001). The Amsterdam Arena: a multi- functional stadium. 323-331.

18. Smith, P. (2014). Sustainable Development \& BIM - The Role of the 5D Quantity Surveyor. Procedia - Social and Behavioral Sciences, 1-11.

19. UEFA. (2011). UEFA Guide to Quality Stadiums. 1-160.

20. Yuan, J., Skibniewski, M. J., Li, Q., \& Zheng, L. (2010). Performance objectives selection model in public-private partnership projects based on the perspective of stakeholders. Journal of Management in Engineering, 26(2), 89-104. https://doi.org/10.1061/(ASCE)ME.19435479.0000011

How to cite this article: Sholichan A, Husin AE. Optimization of M-PERT \& BIM 5D to minimize the risk of time delay \& overrun in stadium project structure works: key success factors. International Journal of Research and Review. 2021; 8(7): 491-498. DOI: https://doi. org/10.52403/ijrr.20210770 